\title{
Relationship between Population and Intensity of Cassava Mealybug (Phenacoccus manihoti) Attack on Flores Island
}

\author{
Yustina MSW Pu'u* \\ Department of Agrotechnology, Faculty of Agriculture, University of Flores, Flores, Indonesia \\ *Corresponding author: yus_puu@yahoo.com
}

\begin{abstract}
This study was conducted to obtain population data and damage due to the attack of Phenacoccus manihoti Cassava mealybug pest on cassava plantations on Flores Island. This research was carried out in Ende Regency, Sikka Regency and Nagekeo Regency, East Nusa Tenggara Province (NTT). The research was conducted in October 2017. Method used in this research was descriptive method with direct observation and sampling. Cassava plants that were observed included plants that grew as fences, yard plants and those in farmers' gardens with an area of \pm 0.5 ha. The variables observed included population abundance and crop damage intensity in all locations of cassava plantations. The average population of Phenacoccus manihoti in each regencyis 131.12 individuals plant $^{-1}$ in Sikka Regency, 36.95 individuals plant ${ }^{-1}$ in Nagekeo Regency and 6.4 individuals plant $^{-1}$ in Ende Regency. Phenacoccus manihoti pest attack intensity in each observation location in the three Regencieson Flores Island is mild to moderate, namely $43.3 \%$ in Sikka Regency; 20\% in Ende Regency and 22\% in Nagekeo Regency. Damage intensity is influenced by cassava mealybug population $15 \%$ and other factors $85 \%$.
\end{abstract}

Keywords: attack intensity, crop pest, mealybug, population

Cite this as: Pu'u, Y. M. S. W. (2019). Relationship between Population and Intensity of Cassava Mealybug (Phenacoccus manihoti) Attack on Flores Island. Caraka Tani: Journal of Sustainable Agriculture, 34(1), 61-66. doi: http://dx.doi.org/10.20961/carakatani.v34i1.25974

\section{INTRODUCTION}

Cassava (Manihot esculenta) is a staple food of the Indonesian population. It is an alternative source of carbohydrates other than rice. Cassava is one of the export commodities that contributes to the country's foreign exchange and also Indonesia is the third largest cassava producer in the world (UN-WFP, 2015). The production of cassava in 1980-2005 increased by an average of $1.77 \%$ per year, while in 2011-2015, the development of cassava production tended to decrease by an average of $0.06 \%$ per year (Pusdatin, 2015). One of the causes is that new pest, namely Cassava mealybug, has been reported to enter Java island for the first time in 2010, especially in Bogor, causing loss of yield between 40-50\% (Muniappan et al., 2011;
Muniappan et al., 2012). Research Abduchalek et al. (2017) studied that Cassava mealybug pest has spread widely in Java.

Cassava mealybug pest Phenacoccus manihoti Matile-Ferrero (Hemiptera: Pseudococcidae) is one of the cassava pests originating from South America, reportedly entered Africa in early 1970s with a yield loss of $82 \%$ (Chakupurakal et al., 1994; Bertschy et al., 2001; Neuenschwander, 2001; Zeddies et al., 2001; Hennessey and Muaka, 2011; Muniappan et al., 2011) and Asia in 2008, it entered Thailand and spread to Cambodia, Laos and Vietnam (Parsa et al., 2012; Sartiami et al., 2015; Le et al., 2018; Upadhyay et al., 2018; Wyckhuys et al., 2018). Pests are thelytokous parthenogenetic which can reproduce all females off spring (Calatayud et al., 2017). Symptoms of

\footnotetext{
* Received for publication December 11, 2018

Accepted after corrections March 31, 2019
} 
the attack are characterized by curling cassava shoots (called bunchy top), shortened book segments and dwarfed plants (Wardani et al., 2014).

Flores, as an archipelago dominated by agriculture, has a large population of farmers. Leading commodities developed include food, horticulture and plantations. Cassava is one of the commodities that is cultivated and is one of the staple foods. The typical cassava that is designated as a superior cultivar is Ubi Nuabosi. This cassava is only cultivated in Ende Regency in one of its sub-districts because it has a specific location.

The presence of Cassava mealybug pest has not yet been reported by the Agriculture Service and the Plant Quarantine Center in Ende Regency. Flores, with a dry climate, allows the development of Cassava mealybug pest and the possibility of high population in the field which is reinforced by statements (Rauf et al., 2017). For this reason, research is needed to obtain preliminary data about the existence and damage of this type of pest on Flores Island. The results of this study form the basis of biological control measures by utilizing natural enemy's in supporting sustainable agriculture. The aim of the study is to obtain damage data due to the attack of Cassava mealybug pest on cassava plantations on Flores Island.

\section{MATERIALS AND METHOD}

The survey was carried out on Flores Island in 3 (three) regencies, namely Ende, Sikka and Nagekeo, East Nusa Tenggara (NTT) Province. The survey was conducted in October 2017. It was a descriptive quantitative method with direct observation and sampling. Each regency has a location with a size of the garden area and yard \pm 0.5-1 ha, with a distance between location points in one sub-district/village at least $1 \mathrm{~km}$. The observation location is recorded using a GPS (Global Positioning System). Observation of white mites was using simple random sampling. The sample was taken from one plot of land and determined five areas of plants. Each area is represented by 10 plants in a diagonal line to obtain 50 sample plants.

The variables observed included population abundance and crop attack intensity in all locations of cassava plantations. Observation of the number of Cassava mealybug started by turning the bottom of all leaves to the top. Pest population was calculated using hand counter, while measurement of crop damage intensity was carried out after observing the population based on visible symptoms. Plant damage was categorized in to five values: normal (worth 0), side of wilted leaves (worth 1), dwarf plants (worth 2), distorted shoots/stems (worth 3) and bunchy top (worth 4) (Neuenschwander et al., 1989).

The abundance data of pest population is presented in the form of an average, while crop damage intensity is calculated using equation:

$$
I=\frac{\sum(n i . v i)}{N . V} x 100 \%
$$

Note:

I = Damage intensity

$\mathrm{Ni} \quad=$ Number of plants with the i-score

$\mathrm{Vi} \quad=$ Attack score

$\mathrm{N} \quad=$ Number of plants observed

$\mathrm{V} \quad=$ Number of plants observed

Number of plants observed (P. Neuenschwander et al., 1989)

Normal $=(0$ white tick $)$

Value 1 Wilted leaves $=(1.9$ white lice $)$

Value 2 Dwarf plants = $(10-99$ Cassava mealybug $)$

Buds/bars are distorted $=(100-999$ Cassava mealybug $)$

Bunchy top $=(.0001,000$ Cassava mealybug $)$

\section{RESULTS AND DISCUSSION}

\section{Phenacoccus manihoti pest population}

Cassava mealybug peston cassava plants at each observation location was different. The average white tick populations in Sikka Regency, Ende Regency and Nagekeo Regency are 131.12 individuals plant ${ }^{-1} ; 6.4$ individuals plant ${ }^{-1}$; and 36.95 individuals plant $^{-1}$ respectively (Table 1 ). The highest population of Cassava mealybug pests in Sikka district and the other two districts shows a low population. The population of white mites is influenced by climatic conditions in all locations suitable for the development of Cassava mealybug.

Climate is an abiotic factor that affects the development of Cassava mealybug pests in the field. Climate includes temperature, humidity, rainfall and wind can increase the distribution and spread of insects. These results are in line with the research of Yonow et al., (2017). Regency has a dry tropical climate, has a temperature that tends to heat with the highest temperature of $35.5^{\circ} \mathrm{C}$ and 
the lowest is $28.1^{\circ} \mathrm{C}$ so the temperature ranges from $27.8^{\circ} \mathrm{C}$ and $30.56{ }^{\circ} \mathrm{C}$. Air humidity between
69.84-83\% (BPS, 2017). This is in line with research Bellotti (2009).

Table 1. Average Phenacoccus manihoti pest population in cassava plants in 3 regencies on Flores Island

\begin{tabular}{clcr}
\hline No. & \multicolumn{1}{c}{ Observation location } & $\begin{array}{c}\text { Third place } \\
(\mathrm{m} \mathrm{dpl})\end{array}$ & $\begin{array}{c}\text { Average } \\
\left.\text { (individuals plant }{ }^{-1}\right)\end{array}$ \\
\hline & Regencies & & \\
\hline 1 & Sikka/Waigete & 21 & 296,02 \\
2 & Sikka/Talibura & 26 & 68,42 \\
3 & Sikka/Nita & 234 & 28,92 \\
& Regencies & 472 & 1,72 \\
4 & Ende/Ende & 530 & 0,42 \\
5 & Ende/Ende Selatan & 128 & 18,80 \\
6 & Ende/Ende Tengah & 9 & 10,76 \\
7 & Ende/Ende Timur & 38 & 4,26 \\
8 & Ende/Ndona & 502 & 1,20 \\
& Regencies & 500 & 36,64 \\
9 & Nagekeo/Boawae/Raja) & 464 & 68,74 \\
10 & Nagekeo/Boawae/Natanage & & \\
11 & Nagekeo/Nangaroro & & \\
\hline
\end{tabular}

Research Wardani et al. (2014) and Wardani (2015) state that higher temperatures with lower air humidity are conditions suitable for the development of Cassava mealybug pests. The climatic conditions of Sikka district are drier than the two districts, so plants are more susceptible to Cassava mealybug. The high population of cassava white mites is high in Africa and South America because every year there is a dry season which causes stress on cassava plants which supports the development of Cassava mealybug populations (Calatayud et al.,1997; Calatayud et al., 2017).

\section{Damage intensity}

The observation results show that the level of damage to cassava plants due to white mite invasionin each location is different. Damage intensity caused by Cassava mealybug pest on cassava plants is different in each location. The average damage intensity in Sikka Regency is $43.3 \%$, Nagekeo is $22 \%$ and Ende is $20 \%$. This is illustrated in terms of the relationship between population and damage intensity (Figure 1).

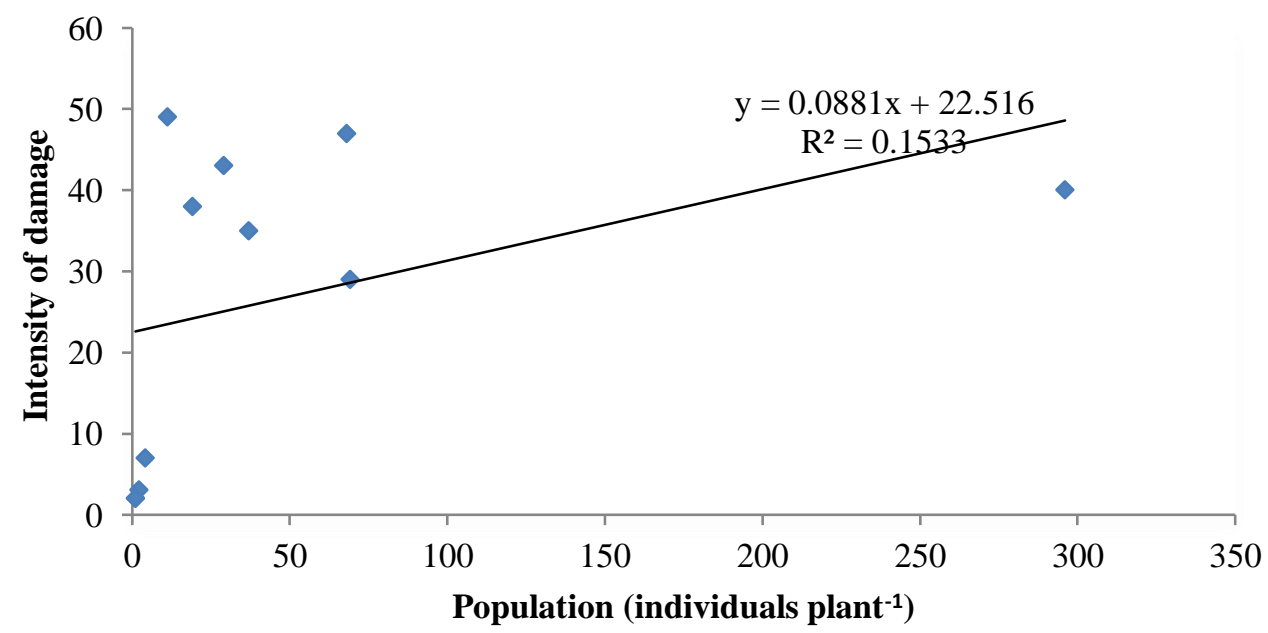

Figure 1. Relationship between population and damage intensity caused by $P$. manihoti in 3 Flores Island Regencies 
The calculation results show that the value of $\mathrm{R}^{2}$ is $15 \%$. This can explain that $\mathrm{R}^{2}$ population variable together can explain the variable variation in damage intensity of $15 \%$ and $85 \%$ by other factors. Data shows that Ende regency has a smaller population than Nagekeo regency but the damage intensity is higher. The influential factor is climate condition, namely rainfall. Research activities were carried out in October but rainfall in Nagekeo Regency was 288 mm (BPS, 2017). This condition causes the Cassava mealybug pest population to be carried mechanically by rainwater. This is reinforced by the results of research by Parsa et al. (2012) and Sartiami et al. (2015). The same thing was said by Schulthess et al. (2011), that rain factors the determinant of pest dynamics. It is supported by Gutierrez et al. (2009) research, that mortality from rainfall is a major determinant of Cassava mealybug population.

The intensity of pest damage is also influenced by plant varieties. The varieties found at the location are local white and yellow species. These types are likely to have low cyanide ( $\mathrm{HCN}$ ) content. Low cyanide content causes cassava to be more resistant to Cassava mealybug. These results are supported by Mutisya et al. (2013); Indiati et al. (2014); Wardani et al. (2014) research. The resistance of cassava plants to white entry involves two intrinsic mechanisms (antixenosis, antibiosis and tolerance) and an extrinsic mechanism. The same results were obtained from research by Tertuliano et al. (2011). Cassava plant varieties which have a higher linamarin content are preferred by pests (Calatayud, 2000).

\section{CONCLUSIONS}

Phenacoccus manihoti pest population on Flores Island spread in 3 locations: Sikka Regency, Ende Regency and Nagekeo Regency; 131.12 individuals plant $^{-1} ; 6.4$ individuals plant $^{-1}$; and 36.95 individuals plant ${ }^{-1}$ respectively. The intensity of damage in Sikka Regency is $43.3 \%$, Nagekeo is $22 \%$ and Ende is $20 \%$, which are categorized as low and medium. The intensity of damage is influenced by cassava mealybug population $15 \%$ and other factors $85 \%$.

\section{REFERENCES}

Abduchalek, B., Rauf, A., \& . P. (2017). Kutu Putih Singkong, Phenacoccus manihoti
Matile-Ferrero (Hemiptera: Pseudococcidae): Persebaran Geografi di Pulau Jawa dan Rintisan Pengendalian Hayati. Jurnal Hama Dan Penyakit Tumbuhan Tropika, 17(1), 1-8. https://doi.org/10.23960/j.hptt.1171-8

Bellotti, A. C. (2009). Arthropod pests. In R. Hillocks, J. M. Thresh, \& A. C. Belottl (Eds.), Cassava: biology, production and utilization (pp. 209-235). Wallingford: CABI Publishing. https://doi.org/10.1079/9780851995243.0209

Bertschy, C., Turlings, T. C. J., Bellotti, A. C., \& Dorn, S. (2001). The role of mealybug-induced cassava plant volatiles in the attraction of the encyrtid parasitoids Aenasius vexans and Apoanagyrus diversicornis. Journal of Insect Behavior, 14(3), 363-371. https://doi.org/ 10.1023/A:1011123413409

Badan Pusat Statistik, [BPS]. (2017). Kabupaten Sikka Dalam Angka 2017. Sikka: BPS Kabupaten Sikka. Retrieved from https:// sikkakab.bps.go.id/publication/2017/08/11/da f1f86981cd62e5eccec216/kabupaten-sikkadalam-angka-2017.html

Calatayud, Paul André., \& Rü, B. Le. (2017). Cassava-Mealybug interactions. CassavaMealybug interactions (1st ed.). Paris: Institute de Recherce Pour Le Development (IRD). https://doi.org/10.4000/books.irdeditions.986 5

Calatayud, P. A. (2000). Influence of linamarin and rutin on biological performances of Phenacoccus manihoti in artificial diets. Entomologia Experimentalis et Applicata, 96(1), 1-64. https://doi.org/10.1023/A:100403 9312918

Calatayud, P. A., Ru, B. le., \& Le Ru, B. (1997). Control of the cassava mealybug in Africa. Cahiers de La Recherche Developpement, 43, 59-66

Chakupurakal, J., Markham, R. H., Neuenschwander, P., Sakala, M., Malambo, C., Mulwanda, D., ... Haug, T. (1994). Biological control of the cassava mealybug, Phenacoccus manihoti (Homoptera: Pseudococcidae), in Zambia. Biological Control, 4(3), 254-262. https://doi.org/ 10.1006/bcon.1994.1032

Gutierrez, A. P., Neuenschwander, P., \& Alphen, 
J. J. M. Van. (2009). Factors Affecting Biological Control of Cassava Mealybug by Exotic Parasitoids: A Ratio-Dependent Supply-Demand Driven Model. The Journal of Applied Ecology, 107(1-5). https://doi.org/ $10.2307 / 2404249$

Hennessey, R. D., \& Muaka, T. (2011). Field biology of the cassava mealybug, Phenacoccus manihoti, and Its natural enemies in Zaire. International Journal of Tropical Insect Science, 8(4-5-6), 899-903. https://doi. org/10.1017/s 1742758400023158

Indiati, S. W., Wahyuni, T. S., Yudha, S., \& Bayu, I. (2014). Toleransi Aksesi Ubi Kayu Terhadap Kepiding Tepung Phenacoccus manihoti, 538-551.

Le, T. T. N., Graziosi, I., Cira, T. M., Gates, M. W., Parker, L., \& Wyckhuys, K. A. G. (2018). Landscape context does not constrain biological control of Phenacoccus manihoti in intensified cassava systems of southern Vietnam. Biological Control, 121, 129-139. https://doi.org/10.1016/j.biocontrol.2018.02.0 11

Muniappan, R., Shepard, B. M., Watson, G. W., Carner, G. R., Rauf, A., Sartiami, D., ... Ziaur Rahman, A. K. M. (2011). New records of invasive insects (Hemiptera: Sternorrhyncha) in Southeast Asia and West Africa. Journal of Agricultural and Urban Entomology, 26(4), 167-174. https://doi.org/10.3954/1523-547526.4.167

Muniappan, R., Vaughan, L., Watson, G. W., Gilbertson, R., \& Noussourou, M. (2012). New Records of Mealybugs, Scale Insects, and Whiteflies (Hemiptera: Sternorrhyncha) from Mali and Senegal. Journal of Agricultural and Urban Entomology, 28,(1), 1-7. https://doi.org /10.3954/1523-5475-28.1.1

Mutisya, D. L., Khamala, C. P. M., Banhawy, E. M. El, Kariuki, C. W., \& Ragwa, S. (2013). Cassava variety tolerance to spider mite attack in relation to leaf cyanide level. Journal of Biology, Agriculture and Healthcare, 3(5), 24-30. Retrieved from http://www.iiste.org/ Journals/index.php/JBAH/article/view/5365

Neuenschwander, P. (2001). Biological control of the cassava mealybug in Africa: A review. Biological Control, 21(3), 214-229. https:// doi.org/10.1006/bcon.2001.0937

Neuenschwander, P., Hammond, W. N. O., Gutierrez, A. P., Cudjoe, A. R., Adjakloe, R., Baumgärtner, J. U., \& Regev, U. (1989). Impact assessment of the biological control of the cassava mealybug, Phenacoccus manihoti Matile-Ferrero (Hemiptera: Pseudococcidae), by the introduced parasitoid Epidinocarsis lopezi (De Santis) (Hymenoptera: Encyrtidae). Bulletin of Entomological Research, 79(4), 579-594. https://doi.org/10.1017/S000748530 0018733

Parsa, S., Kondo, T., \& Winotai, A. (2012). The Cassava Mealybug (Phenacoccus manihoti) in Asia: First Records, Potential Distribution, and an Identification Key. PLoS ONE, 7(10), e47675. https://doi.org/10.1371/journal.pone. 0047675

Pusat Data dan Sistem Informasi Pertanian Kementerian Pertanian, [Pusdatin]. (2015). Outlook Komoditas Pertanian Tanaman Pangan: Ubi Kayu. Pusat Data dan Sistem Informasi Pertanian Kementerian Pertanian: Jakarta. Retrieved from http://epublikasi. setjen.pertanian.go.id/epublikasi/outlook/201 5/Tanaman\%20Pangan/Outlook\%20Ubikayu $\% 202015 /$ files/assets/common/downloads/Ou tlook\%20Ubikayu\%202015.pdf

Rauf, A., Pudjianto, P., \& Adriani, E. (2017). Laju enkapsulasi parasitoid Anagyrus lopezi (De Santis) (Hymenoptera: Encyrtidae) oleh kutu putih singkong Phenacoccus manihoti MatileFerrero (Hemiptera: Pseudococcidae). Jurnal Entomologi Indonesia, 13(3), 147-155. https:// doi.org/10.5994/jei.13.3.147

Sartiami, D., Watson, G. W., Mohamad Roff, M. N., Mohd Hanifah, Y., \& Idris, A. B. (2015). First record of cassava mealybug, Phenacoccus manihoti (Hemiptera: Pseudococcidae), in Malaysia. Zootaxa, 3957(2), 235-238. https://doi.org/10.11646/ zootaxa.3957.2.8

Schulthess, F., Baumgärtner, J. U., \& Herren, H. R. (1987). Factors influencing the life table statistics of the cassava mealybug Phenacoccus manihoti. International Journal of Tropical Insect Science, 8(4-5-6), 851-856. https://doi.org/10.1017/s1742758400023055

Singh, A. S., \&Masuku, M. B. (2014). King of 
charcoal: Japanese create new life for dying industry. International Journal of Economics, Commerce and Management, 2(11), 1-22.

Tertuliano, M., Dossou-Gbete, S., \& Le Rü, B. (2011). Antixenotic and antibiotic components of resistance to the cassava mealybug Phenacoccus manihoti (Homoptera: Pseudococcidae) in various host-plants. International Journal of Tropical Insect Science, 14(5-6), 657-665. https://doi.org/ $10.1017 / \mathrm{s} 1742758400018087$

UN-WFP. (2015). Peta Ketahanan dan Kerentanan Pangan Nusa Tenggara Timur Tahun 2015.Pemerintah Provinsi Nusa Tenggara Timur, Dewan Ketahanan Pangan, Kementerian Pertanian and World Food Programme (WFP).

Upadhyay, B., Burra, D. D., Nguyen, T. T., \& Wyckhuys, K. A. G. (2018). Caught off guard: folk knowledge proves deficient when addressing invasive pests in Asian cassava systems. Environment, Development and Sustainability, 15(5), 1-21. https://doi.org/ 10.1007/s10668-018-0208-x

Wardani, N. (2015). Kutu Putih Ubi Kayu, Phenacoccus Manihoti Matile-Ferrero (Hemiptera: Pseudococcidae), Hama Invasif Baru di Indonesia. Retrieved from https://repository.ipb.ac.id/handle/123456789/
75174

Wardani, N., Rauf, A., Winasa, I. W., \& Santoso, S. (2014). Parameter Neraca Hayati dan Pertumbuhan Populasi Kutu Putih Phenacoccus manihoti Matile-Ferrero (Hemiptera: Pseudococcidae) pada Dua Varietas Ubi Kayu. J. HPT Tropika, 14(1), 6470. Retrieved from http://jhpttropika.fp.unila. ac.id/index.php/jhpttropika/article/view/311

Wyckhuys, K. A. G., Zhang, W., Prager, S. D., Kramer, D. B., Delaquis, E., Gonzalez, C. E., \& Van Der Werf, W. (2018). Biological control of an invasive pest eases pressures on global commodity markets. Environmental Research Letters, 13(9), 1-13. https://doi.org/ 10.1088/1748-9326/aad8f0

Yonow, T., Kriticos, D. J., \& Ota, N. (2017). The potential distribution of cassava mealybug (Phenacoccus manihoti), a threat to food security for the poor. PLoS ONE, 12(3), e0173265. https://doi.org/10.1371/journal. pone. 0173265

Zeddies, J., Schaab, R. P., Neuenschwander, P., \& Herren, H. R. (2001). Economics of biological control of cassava mealybug in Africa. Agricultural Economics, 24(2), 209-219. https://doi.org/10.1016/S0169-5150(00)00064 $-5$ 